\title{
Vertical distribution and feeding of the carnivorous copepod Paraeuchaeta norvegica
}

\author{
Hilde Skarra, Stein Kaartvedt* \\ University of Oslo, Department of Biology, PO Box 1064 Blindern, 0316 Oslo, Norway
}

\begin{abstract}
Adult females of Paraeuchaeta norvegica inhabited the lower part of a $200 \mathrm{~m}$ deep water column in winter and early spring, while their distribution became more shallow during summer and comprised both a deep and a shallow mode during autumn. Day and night profiles were fairly similar, although with slightly shallower population distributions at night. $P$. norvegica produced fecal pellets at all seasons. Enumeration of the egested pellets suggested greatest feeding activity during late autumn and least during winter. Pellets were produced at all depths. Feeding activity was greatest at night.
\end{abstract}

KEY WORDS: Diel vertical migration $\cdot$ Fecal pellets $\cdot$ Season

Resale or republication not permitted without written consent of the publisher

\section{INTRODUCTION}

The carnivorous copepod Paraeuchaeta norvegica is a common constituent of the zooplankton of fjords and oceanic waters (Østvedt 1955, Bakke 1977, Mauchline 1995, Park 1995, Dale et al. 1999), and is assumed to play an important role in the pelagic food chain (Båmstedt \& Skjoldal 1976, Bakke 1977, Bathmann et al. 1990, Eiane et al. 2002). Adult female $P$. norvegica attain prosome lengths $>5 \mathrm{~mm}$ in Norwegian fjords (Kaartvedt et al. 2002), and such large copepods are susceptible to visual predators (O'Brien 1979). Typically, large copepods live relatively deep during daytime and migrate into shallow waters at night. This diel vertical migration may reflect the needs of avoiding predators and finding prey (Bollens \& Frost 1991, Hays et al. 1994). However, little is known about diel or seasonal patterns in vertical distributions and feeding of $P$. norvegica (but see Fleddum et al. 2001, Kaartvedt et al. 2002).

Adult females of Paraeuchaeta spp. are most efficient in capturing smaller-sized prey like copepods of $\sim 1 \mathrm{~mm}$ prosome length (Yen 1983, Greene \& Landry 1985, Olsen et al. 2000). However, a range of prey sizes, including Calanus spp., can be handled (Båmstedt \& Holt 1978, Øresland 1991, Øresland \& Ward 1993). Small copepods prevail in near-surface waters during summer and autumn, possibly being preyed on at night (Kaartvedt et al. 2002). Organisms like Calanus spp., which spend parts of their life-cycle in deep water, may serve as food for Paraeuchaeta spp. at depth (Fleddum et al. 2001). However, Paraeuchaeta spp. are tactile predators (Yen 1987) that may be unable to efficiently locate and exploit dormant copepods, and Yen (1991) suggested that $P$. antarctica might cease feeding during winter.

Fjords represent relatively deep and readily accessible near-shore habitats, thereby providing unique opportunities for studies of deep-living organisms. Here we address the vertical distribution and feeding of adult female Paraeuchaeta norvegica in the Oslofjord, Norway. The specific goals were to establish vertical distributions of $P$. norvegica during day and night throughout the year, and to describe feeding patterns in relation to time of day, season, and depth.

\section{MATERIALS AND METHODS}

The study was carried out at a $200 \mathrm{~m}$ deep location during 7 cruises in 1997-98 (5 March, 29 April, 12 June, 25 August, 21 October, and 20 November 1997; and 9 February 1998). The study site (59³8' N, $\left.10^{\circ} 38^{\prime} \mathrm{E}\right)$ was located in the Drøbak Sound that separates the inner and outer Oslofjord (Fig. 1). Sampling was carried out from RV 'Trygve Braarud', except for June, when sampling was performed from RV 'Bjørn Føyn'.

Salinity and temperature were measured with a Neil Brown Mark III CTD, except for June, when we used a portable mini-CTD. 


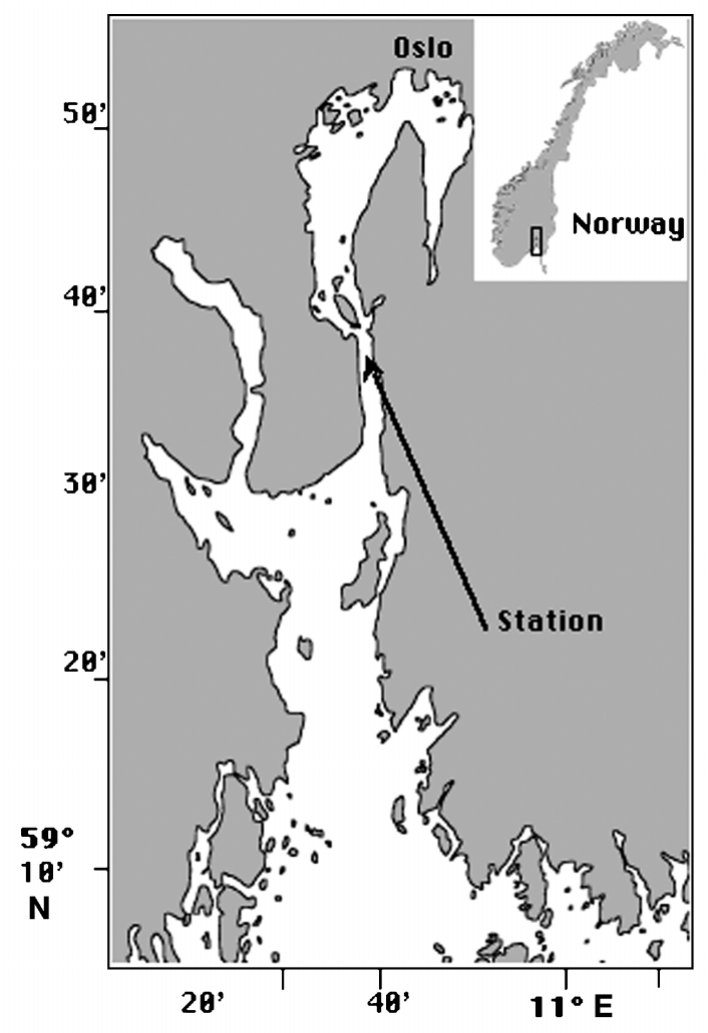

Fig. 1. Map of the study area

We assessed the vertical distribution of Paraeuchaeta norvegica and their potential prey by depth- stratified net-sampling covering the whole water column. Potential prey organisms were sampled with a WP-2 net (200 $\mu \mathrm{m}$ mesh size) in series comprising $4 \times 50 \mathrm{~m}$ depth intervals. Two parallel series were obtained both day and night. Samples were preserved in $4 \%$ formalin. Biomass (wet weight of the preserved sample) was determined for 3 size categories, i.e. animals retained by sieves with mesh sizes of 2, 1 and $0.125 \mathrm{~mm}$, respectively. Each subsample was filtered onto a preweighed (wet) GF/C filter before weighing.

Paraeuchaeta norvegica was sampled in the same 4 depth intervals by a modified Nansen net (mesh size $500 \mu \mathrm{m})$, equipped with a non-filtering cod-end. Four parallel series were taken both day and night, except for October, when only 2 daytime series were obtained before onset of darkness. All females in each sample were counted.

For comparisons of vertical distribution, weighted mean depth (WMD) was calculated as in Roe et al. (1984). We also estimated the average pellet production (see below) of Paraeuchaeta norvegica for the entire water column. Differences in WMD and pellet production between day and night, and between sampling dates, were tested by using 2-way ANOVA and subsequent Tukey's HSD post hoc test.

Feeding was assessed by enumerating fecal pellets egested from freshly collected females. The number of egested pellets was assumed to be a representative measure for the feeding status at the time of capture. All captured females were included in the study, in total 1000 individuals. Laboratory results have shown a strong linear relation between food intake and number of pellets produced (Yen 1987, 1991, Tiselius et al. 1997, Olsen et al. 2000), although the number of pellets egested in relation to amount of food eaten may depend on food types (Yen 1987).

Daytime sampling was always initiated several hours after sunrise in order to reduce the impact from previous feeding at night. Sampling at night was normally initiated more than $2 \mathrm{~h}$ after sunset. Immediately upon retrieval of the net, all adult females of Paraeuchaeta norvegica were rinsed with filtered seawater. They were transferred to $50 \mathrm{ml}$ vials filled with filtered seawater and incubated in a refrigerator at ca. $6^{\circ} \mathrm{C}$ within $\sim 10 \mathrm{~min}$ after capture. A maximum of 6 individuals were kept per vial. After 20 to $24 \mathrm{~h}$, the copepods were removed and the water filtered onto GF/C or GF/F filters to retrieve pellets produced during the incubation. During 2 experiments measuring the gut evacuation rates (Skarra 1999), no pellets were found to be produced after $17 \mathrm{~h}$, suggesting that guts would be emptied in the course of the incubation period. Filters were stored in individual petri dishes and frozen at $-20^{\circ} \mathrm{C}$. The filters were examined at 16 to $32 \times$ magnification, and the pellets were enumerated and measured for length using a micro-occular. Variation in pellet size as a function of depth, season and time of day was tested by linear regression.

\section{RESULTS}

\section{Hydrography}

The surface temperature fluctuated between 2.5 (February) and $22^{\circ} \mathrm{C}$ (August), and the salinity varied between 21 (August) and 31 ppt (April) (Fig. 2). The temperature below $50 \mathrm{~m}$ was 6 to $7^{\circ} \mathrm{C}$ on most cruises, except for October, when the temperature was above $10^{\circ} \mathrm{C}$ in the uppermost $60 \mathrm{~m}$, and in November, when there was a temperature maximum of $11.5^{\circ} \mathrm{C}$ at $75 \mathrm{~m}$. Salinity below $50 \mathrm{~m}$ was always above $33 \mathrm{ppt}$, with the maximum value of 34.7 ppt occurring in February.

\section{Zooplankton biomass}

The abundance of zooplankton in the smallest size fraction was at a minimum in February (Fig. 3). Apart from this cruise, the smallest size fraction was most abundant in the upper $50 \mathrm{~m}$. There was generally a biomass minimum at 50 to $100 \mathrm{~m}$ for this group, except 


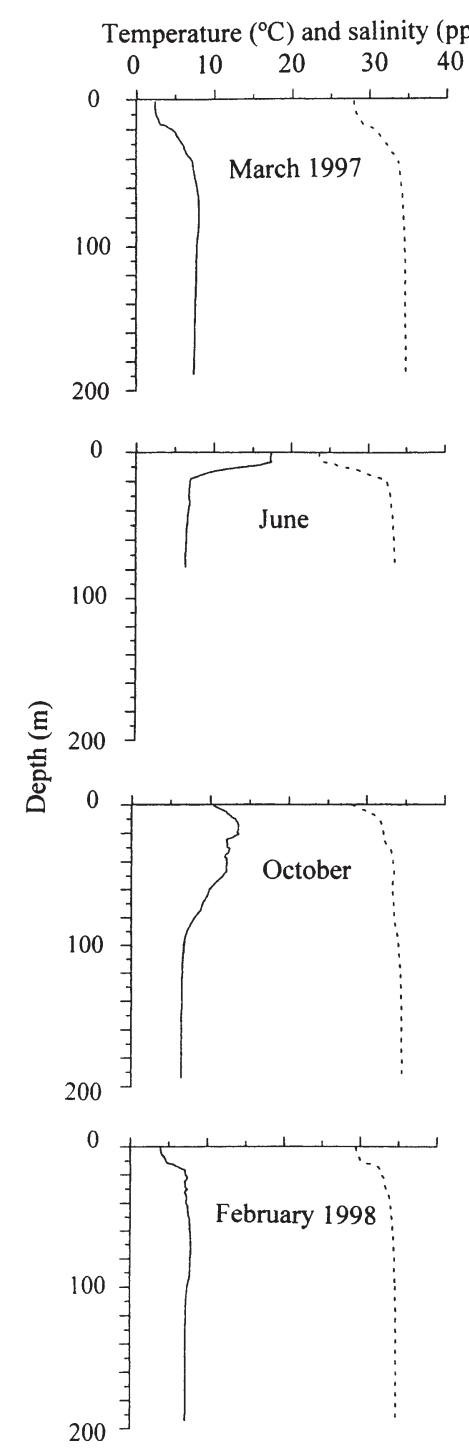

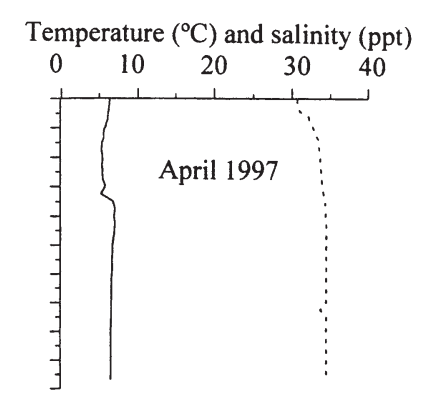
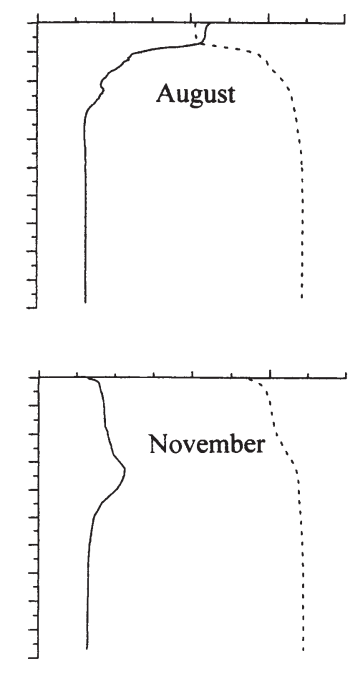

Fig. 2. Temperature (solid line) and salinity (stippled line)

for April, when the abundance decreased with depth. Organisms between 1 and $2 \mathrm{~mm}$ showed less variation in abundance between cruises, and were distributed more evenly throughout the water column, though usually with the highest catches in the 2 deepest intervals during the daytime. The largest size group was most abundant in deep water, with highest catches in April and June (Fig. 3).

\section{Paraeuchaeta norvegica}

\section{Vertical distribution}

Paraeuchaeta norvegica was most abundant between 150 and $200 \mathrm{~m}$ (Fig. 4). It stayed deepest early in the year (Figs. 4 \& 5), and WMDs were significantly deeper in March and February than during all other

cruises ( $p<0.001$ to 0.031 , depending on cruise). The vertical distribution became more dispersed during summer and autumn (Fig. 4). A bimodal daytime distribution was indicated in October, when females mainly occurred between 200-150 $\mathrm{m}$ and 100-50 m.

Day and night profiles were fairly similar (Fig. 4). Paraeuchaeta norvegica was most abundant in the deepest interval day and night, and only few individuals were captured in the shallowest interval at night. However, for the whole data set combined, the WMDs were significantly shallower at night than during the day $(\mathrm{p}<0.001)$, with amplitudes ranging between 0 and $31 \mathrm{~m}$ (June and April, respectively; Fig. 5).

\section{Fecal pellets}

Paraeuchaeta norvegica produced fecal pellets in all seasons (Figs. 4 \& 6). The numbers were highest in November (significantly higher than during all other cruises; $\mathrm{p}<0.001$ to 0.023 ), while the lowest numbers were recorded in February. The number of pellets produced was higher for individuals captured at night than during the daytime (Fig. 6 ; p < 0.001). Pellets were produced at all depths (Fig. 4). By comparing all day and night profiles, respectively, maximum pellet production was recorded from all sampling depths on at least 1 cruise (except for the upper $50 \mathrm{~m}$ during the day), most frequently between 50 and $100 \mathrm{~m}$ at night. The greatest pellet production was recorded for individuals captured between 50 and $100 \mathrm{~m}$ at night in November (Fig. 4).

For all data combined, there was no difference between average pellet length from day (486 $\mu \mathrm{m})$ and night $(484 \mu \mathrm{m})$. Pellet lengths were fairly constant between cruises (Fig. 7), but still significantly shorter in February than in March and November $(p<0.05)$. Pellets in March were furthermore longer than in June $(p<0.05)$. There was a slight, but significant, increase in pellet length with depth $(\mathrm{p}<0.05)$.

\section{DISCUSSION}

Paraeuchaeta norvegica lived deepest during winter. Their distribution became shallower during summer and comprised both a deep and a shallow mode during autumn. Fluctuations between surveys are not proof of systematic seasonal variations, but the trend appeared to be regular and the results concur with the few pre- 


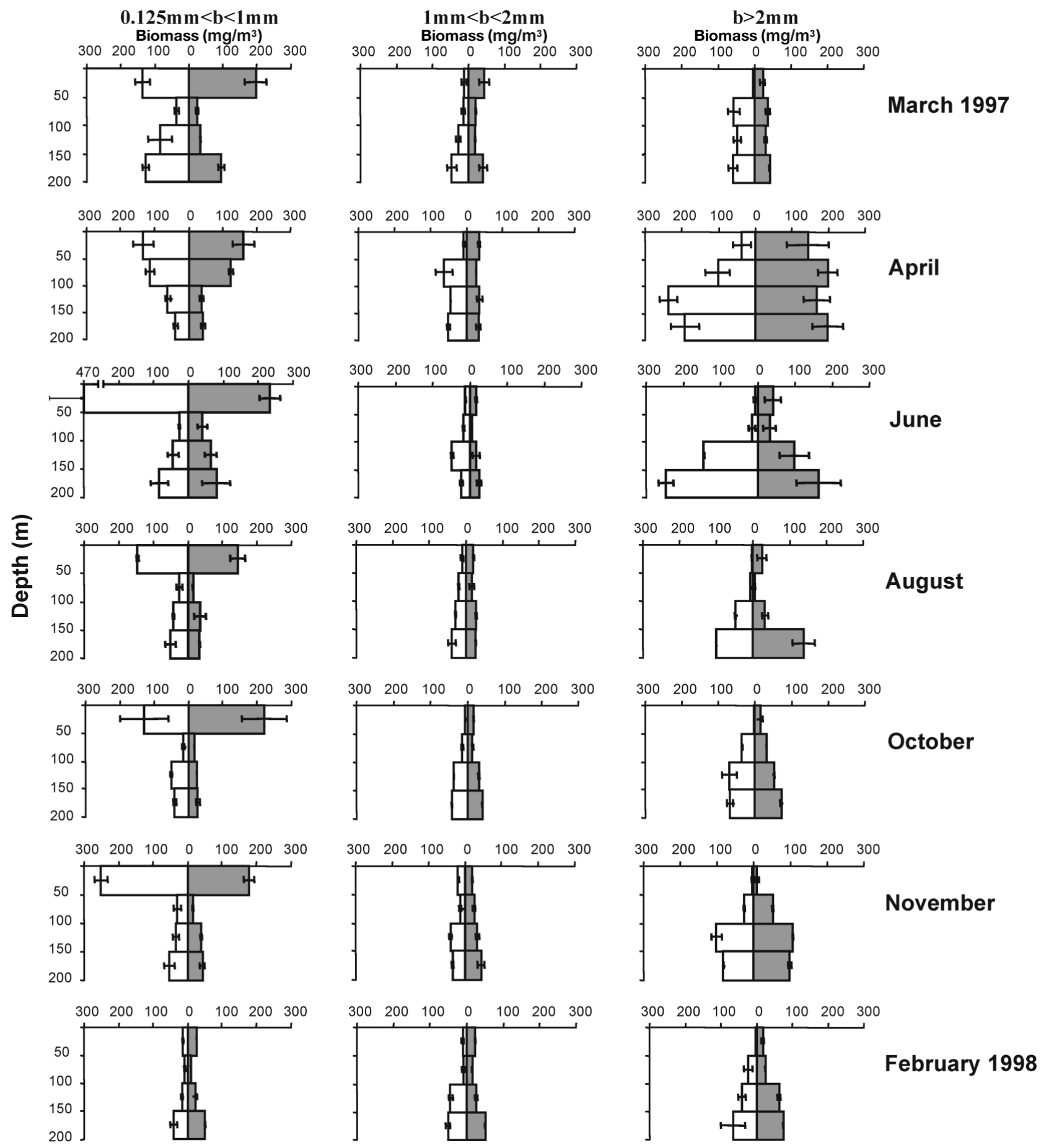

Fig. 3. Vertical biomass (wet weight \pm SE) distribution, during day- (open) and night- (filled) time, of potential prey allocated to size categories. b: mesh sizer

viously published records on this species from other Norwegian fjords. Data in Baliño \& Aksnes (1993) reveal that adult $P$. norvegica stayed in deep water both day and night in January, and Kaartvedt et al.
(2002) documented bi-modal daytime distributions for $P$. norvegica during autumn. Diel vertical migration (DVM) was recorded for the shallow mode (Kaartvedt et al. 2002). 


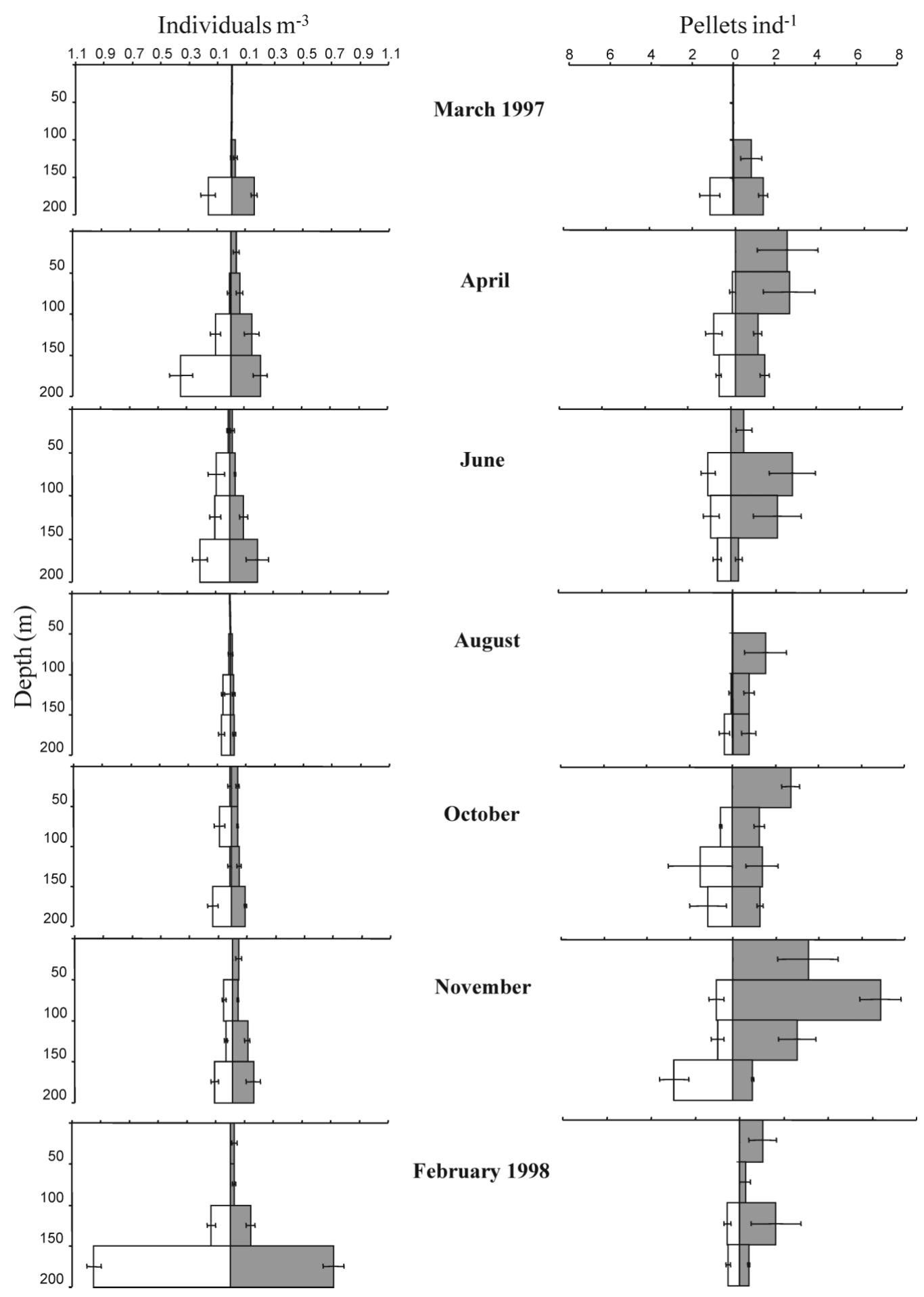

Fig. 4. Paraeuchaeta norvegica. Vertical distribution of adult females and pellet production during day- (open) and night- (filled) time. Bars denote \pm SE

We generally observed fairly similar day and night profiles, although with slightly shallower population distributions at night. Hays et al. (2001) reported that individuals of the copepod Metridia pacifica that migrated towards the surface at night had much smaller oil sacks than individuals in the same population remaining at depth. This was ascribed to 'fat' individuals prioritizing predator avoidance in deep water rather than risky feeding in upper waters (Hays et al. 2001). 


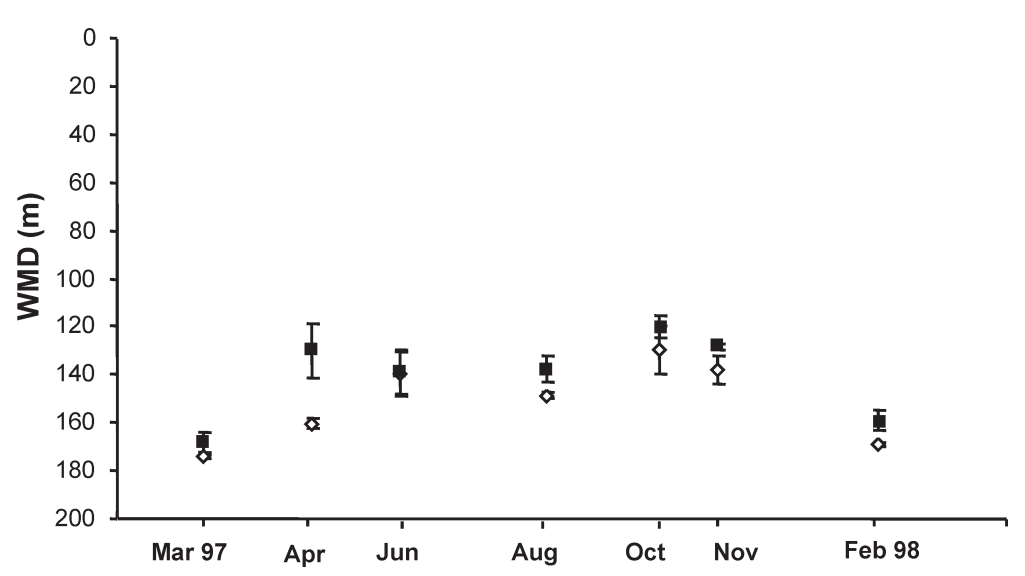

Fig. 5. Paraeuchaeta norvegica. Weighted mean depth $(\mathrm{WMD}) \pm \mathrm{SE}$ during day- (open) and night- (filled) time

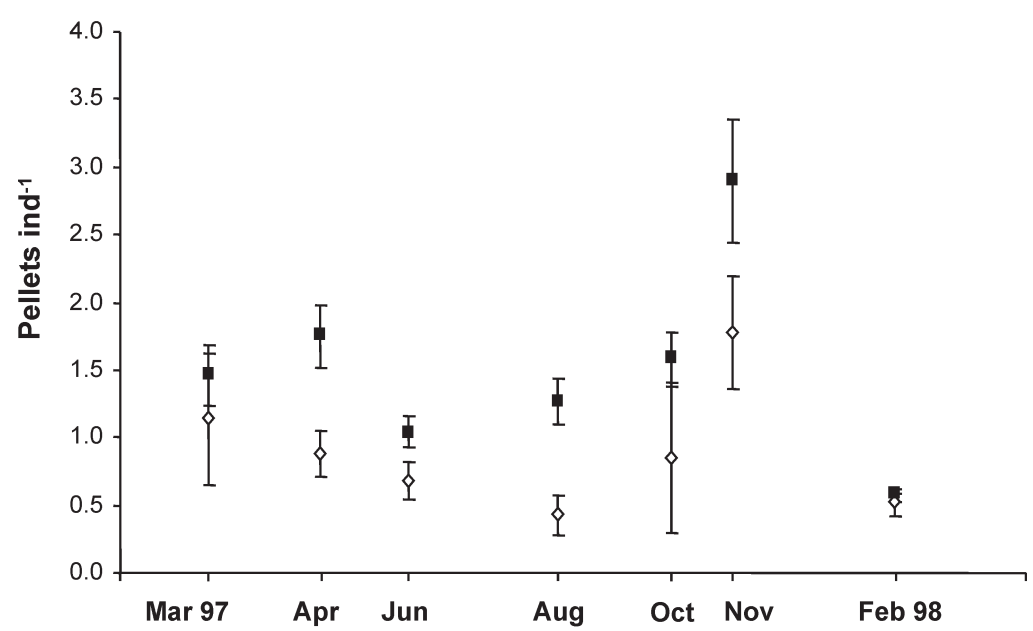

Fig. 6. Paraeuchaeta norvegica. Average pellet production $( \pm \mathrm{SE})$ for the water column during day- (open) and night- (filled) time

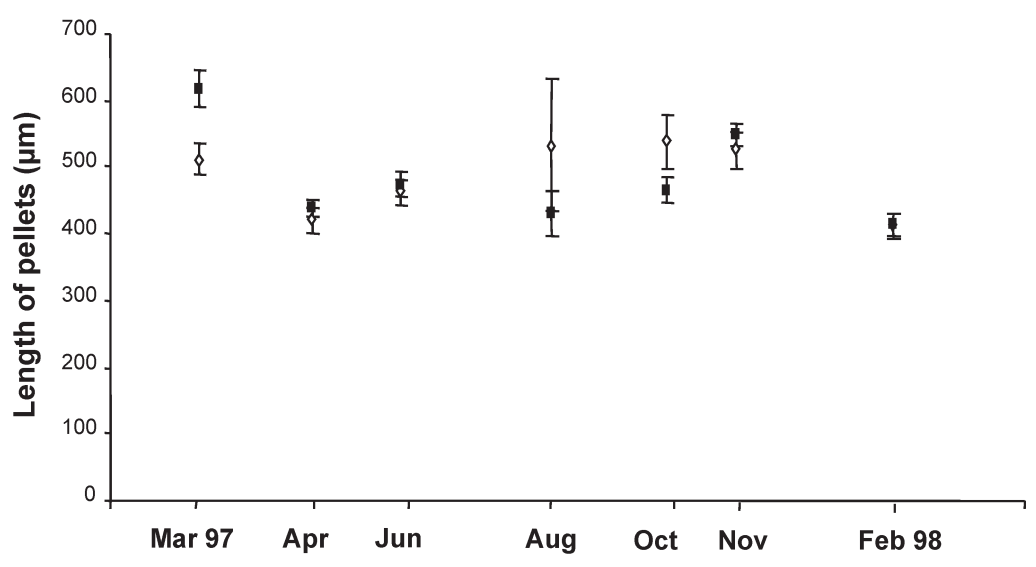

Fig. 7. Paraeuchaeta norvegica. Average length of pellets $( \pm \mathrm{SE})$ during day- (open) and night- (filled) time
Paraeuchaeta norvegica was foraging throughout the year. Feeding was, however, apparently lowest in February, as derived from the combination of the lowest number and smallest size of the pellets. This concurred with the lowest potential prey abundance in the size class $<1 \mathrm{~mm}$, which is expected to represent the most relevant food organisms for Paraeuchaeta spp. (Yen 1983, 1985, Greene \& Landry 1985, Olsen 1996). Also, juveniles of $P$. norvegica displayed the lowest feeding in February (results presented in Skarra 1999), and in that case pellet production was only recorded from individuals sampled at night.

Feeding activity appeared to peak in November, as derived from the greatest numbers of pellets and large pellet size at that time. However, prey availability (as expressed by biomass) did not exceed that during previous cruises, and the pellet production by juveniles assessed by Skarra (1999) did not show a corresponding peak. This specific response for adult females may be related to enhanced motivation for feeding. Other studies of Paraeuchaeta norvegica suggest maximal egg production in winter, supported by lipid reserves of the females (Bakke 1977, Båmstedt 1979, Hopkins 1982, Mauchline 1994), although reproducing females are present year-round in the Oslofjord (Wiborg 1940). Since accumulation of wax esters may permit production of eggs in Paraeuchaeta spp. during times of unfavorable food conditions in winter (e.g. Alonzo et al. 2000), a build-up of lipid reserves in autumn may be essential. Neither Yen (1982) nor Olsen (1996) found significant effects of female reproductive status in experimental studies of feeding in Paraeuchaeta spp.

Feeding was most prominent at night, but Paraeuchaeta norvegica also seemed to forage during the day, although results from daytime may have been influenced by remnants or initiation of nocturnal feeding. The greatest records of suggested daytime feeding were from October and November (Fig. 4). The short days at this time of year resulted in sampling close to sunset (Skarra 1999), and we cannot exclude that samples from late in the day actually reflected the beginning of nocturnal feeding in deep water. Since this potential bias will lead to overestimation of daytime feeding, our 
conclusion of enhanced feeding at night is conservative. Olsen et al. (2000) experimentally demonstrated an endogenous rhythm of enhanced feeding at night in Paraeuchaeta norvegica from the same location as this study (see also Yen 1982). The search for food exposes copepods to predators (cf. Tiselius et al. 1997), and this may depress daytime feeding, even in deep water. In any case, the documentation of deep-living individuals with relatively high gut content late during the day (Skarra 1999) suggests that $P$. norvegica at times was foraging successfully in deep water.

On several occasions, high nocturnal production of pellets was measured at 50 to $100 \mathrm{~m}$, even if this represented a stratum with minimum zooplankton biomass during most surveys. This could possibly be explained by short feeding excursions to upper layers, with a return to somewhat deeper, safer water for digestion (cf. Pearre 1979). Adult female Paraeuchaeta spp. may be vulnerable to visual predators even at night (Bollens \& Frost 1991), and could therefore be prone to minimizing time spent in upper layers. In November, representing the most evident example of large production of pellets from individuals captured between 50 and $100 \mathrm{~m}$, an additional bonus of sinking down after foraging would be enhanced digestion in the sub-surface temperature peak which occurred in this depth interval during that cruise (cf. Giske \& Aksnes 1992, Loose \& Dawidowicz 1994).

\section{LITERATURE CITED}

Alonzo F, Mayzaud P, Razouls S (2000) Egg production, population structure and biochemical composition of the subantarctic copepod Paraeuchaeta antarctica in the Kerguelen Archipelago. Mar Ecol Prog Ser 205:207-217

Bakke JLW (1977) Ecological studies on the deepwater pelagic community of Korsfjorden, western Norway. Population dynamics of Euchaeta norvegica (Crustacea, Copepoda) from 1971 to 1974. Sarsia 63:49-55

Baliño BM, Aksnes DL (1993) Winter distribution and migration of the sound scattering layers, zooplankton and micronekton in the Masfjorden, western Norway. Mar Ecol Prog Ser 102:35-50

Båmstedt U (1979) Reproductive bioenergetics within the summer and winter generations of Euchaeta norvegica (Copepoda). Mar Biol 54:135-142

Båmstedt U, Holt MR (1978) Experimental studies on the deep-water pelagic community of Korsfjorden, western Norway. Prey-size preference and feeding of Euchaeta norvegica (Copepoda) in relation to its life cycle. Sarsia 63: 225-236

Båmstedt U, Skjoldal HR (1976) Studies on the deep-water pelagic community of Korsfjorden, western Norway. Adenosine phosphates and nucleic acids in Euchaeta norvegica (Copepoda) in relation to its life cycle. Sarsia 60: $63-80$

Bathmann UV, Noji TT, von Bodungen B (1990) Copepod grazing potential in late winter in the Norwegian Sea - a factor in the control of spring phytoplankton growth? Mar Ecol Prog Ser 60:225-233
Bollens SM, Frost BW (1991) Ovigerity, selective predation, and variable diel vertical migration in Euchaeta elongata (Copepoda: Calanoida). Oecologia 87:155-161

Dale T, Bagøien E, Melle W, Kaartvedt S (1999) Can predator avoidance explain varying overwintering depth of Calanus in different oceanic water masses? Mar Ecol Prog Ser 179:113-121

Eiane K, Aksnes DL, Ohman MD, Wood S, Martinussen MB (2002) Stage-specific mortality of Calanus spp. under different predation regimes. Limnol Oceanogr 47:636-645

Fleddum AL, Kaartvedt S, Ellertsen B (2001) Distribution and feeding of the carnivorous copepod Paraeuchaeta norvegica in habitats of shallow prey assemblages and midnight sun. Mar Biol 139:719-726

Giske J, Aksnes DL (1992) Ontogeny, season and trade-offs: vertical distribution of the mesopelagic fish Maurolicus muelleri. Sarsia 77:253-261

Greene CH, Landry MR (1985) Patterns of prey selection in the cruising calanoid predator Euchaeta elongata. Ecology 66:1408-1416

Hays GC, Proctor CA, John AWG, Warner AJ (1994) Interspecific differences in the diel vertical migration of marine copepods. The implications of size, color and morphology. Limnol Oceanogr 39:1621-1629

Hays GC, Kennedy H, Frost BW (2001) Individual variability in diel vertical migration of a marine copepod: why some individuals remain at depth when others migrate. Limnol Oceanogr 46:2050-2054

Hopkins CCE (1982) The breeding biology of Euchaeta norvegica (Boeck) (Copepoda: Calanoida) in Loch Etive, Scotland: assessment of breeding intensity in terms of seasonal cycles in the sex ratio, spermatophore attachment and egg-sac production. J Exp Mar Biol Ecol 60:91-102

Kaartvedt S, Dale T, Bagøien E, Viken T (2002) Bi-modal vertical distribution of the carnivorous copepod Paraeuchaeta norvegica. J Plankton Res 24:155-158

Loose CJ, Dawidowicz P (1994) Trade-offs in diel vertical migration by zooplankton: the costs of predator avoidance. Ecology 75:2255-2263

Mauchline J (1994) Seasonal variations in some population parameters of Euchaeta species (Copepoda: Calanoida). Mar Biol 120:561-570

Mauchline J (1995) Bathymetric adaptations of life history patterns of congeneric species (Euchaeta: Calanoida) in a 2000 m water column. ICES J Mar Sci 52:511-516

O'Brien WJ (1979) The predator-prey interaction of planktivorous fish and zooplankton. Am Sci 67:572-579

Olsen EM (1996) Eksperimentelle studier av fødeinntak hos den carnivore copepoden Paraeuchaeta norvegica (Boeck). MSc thesis, University of Oslo

Olsen EM, Jørstad T, Kaartvedt S (2000) The feeding strategies of two large marine copepods. J Plankton Res 22: 1513-1528, 2000

Øresland V (1991) Feeding of the carnivorous copepod Euchaeta antarctica in Antarctic waters. Mar Ecol Prog Ser 78:41-47

Øresland V, Ward P (1993) Summer and winter diet of four carnivorous copepod species around South Georgia. Mar Ecol Prog Ser 98:73-78

Østvedt OJ (1955) Zooplankton investigations from weathership M in the Norwegian Sea, 1948-1949. Hvalråd Skr 40:1-93

Park T (1995) Taxonomy and distribution of the marine calanoid copepod family Euchaetidae. Bull Scripps Inst Oceanogr Univ Calif 29:1-107

Pearre S Jr (1979) Problems of detection and interpretation of vertical migration. J Plankton Res 1:29-44 
Roe HSJ, Angel MV, Badcock J, Domanski P, James PT, Pugh $\mathrm{PR}$, Thurston MH (1984) The diel migrations and distributions within a mesopelagic community in the north east Atlantic. 1. Introduction and sampling procedures. Prog Oceanogr 13:245-268

Skarra H (1999) Vertikalfordeling og fødeinntak hos den carnivore copepoden Euchaeta norvegica i Oslofjorden. MSc thesis, University of Oslo

Tiselius P, Jonsson P, Kaartvedt S, Olsen ME, Jørstad T (1997) Effects of foraging behavior on predation risk: an experimental study of the predatory copepod Pareuchaeta norvegica feeding on Acartia clausi and A. tonsa (Copepoda). Limnol Oceanogr 42:164-170

Wiborg K F (1940) The production of zooplankton in the Oslo Fjord in 1933-1934. Hvalråd Skr 21:1-87

Yen J (1982) Sources of variability in attack rates of Euchaeta

Editorial responsibility: Otto Kinne (Editor),

Oldendorf/Luhe, Germany elongata Esterly, a carnivorous marine copepod. J Exp Mar Biol Ecol 63:105-117

Yen J (1983) Effects of prey concentration, prey size, predator life stage, predator starvation, and season on predation rates of the carnivorous copepod Euchaeta elongata. Mar Biol 75:69-77

Yen J (1985) Selective predation by the carnivorous marine copepod Euchaeta elongata: laboratory measurements of predation rates verified by field observations of temporal and spatial feeding patterns. Limnol Oceanogr 30: $577-597$

Yen J (1987) Predation by Euchaeta norvegica Boeck on eggs and larvae of the Atlantic cod Gadus morhua L. J Exp Mar Biol Ecol 112:283-296

Yen J (1991) Predatory feeding behavior of an Antarctic marine copepod, Euchaeta antarctica. Polar Res 10:433-442

Submitted: January 22, 2001; Accepted: November 6, 2002

Proofs received from author(s): February 13, 2003 